\title{
Life-threatening reaction of a pediatric cancer patient to sodium hypochlorite
}

\author{
Reação potencialmente fatal ao hipoclorito de sódio em paciente pediátrico com câncer \\ Reacción potencialmente mortal al hipoclorito de sodio de un paciente pediátrico con cáncer
}

Received: 09/10/2021 | Reviewed: 09/20/2021 | Accept: 10/11/2021| Published: 10/12/2021

Bruna da Fonseca Wastner

ORCID: https://orcid.org/0000-0002-9056-3733 Erasto Gaertner Cancer Center, Brazil Universidade Federal do Paraná, Brazil E-mail: bucobw@gmail.com

Mariana de Souza Lessa

ORCID: https://orcid.org/0000-0001-8204-5787 Erasto Gaertner Cancer Center, Brazil

E-mail: marianadslessa@gmail.com

Laurindo Moacir Sassi

ORCID: https://orcid.org/0000-0002-9333-2498 Erasto Gaertner Cancer Center, Brazil

E-mail: sassilaurindo@gmail.com

Mara Albonei Dudeque Pianovski

ORCID: https://orcid.org/0000-0003-0260-8506 Erasto Gaertner Cancer Center, Brazil Universidade Federal do Paraná, Brazil

E-mail: mpianovski@erastogaertner.com.br

\begin{abstract}
The use of sodium hypochlorite $(\mathrm{NaOCl})$ as irrigation solution in endodontics is widespread and accidents of apical extravasation may occur, being in most cases mild to moderate situations of simple management. However, in immunosuppressed patients, the reaction may be exacerbated, with significant systemic changes and potentially lifethreatening. Even so, there is a lack of information about the management of these special cases, especially in oncopediatric cases. Therefore, the aim is to report a case of severe reaction post-accident with $\mathrm{NaOCl}$ in a 13-yearold adolescent undergoing chemotherapy, with significant edema, gingival necrosis, cutaneous rash, edema of the extremities, pleural effusion, and bronchopneumonia, with a 30-day evolution. It is understood that several factors, including anatomical, may predispose this situation, which can occur even with expert and experienced professionals, not necessarily associated with poor practice. The authors raise the importance of further studies to discuss the real need and indication of the use of $\mathrm{NaOCl}$ as an irrigating solution for these patients and suggest the adoption of extra safety measures to avoid the occurrence of similar situations.
\end{abstract}

Keywords: Sodium hypochorite; Neutropenia; Pediatrics; Endodontics.

Resumo

O uso de hipoclorito de sódio $(\mathrm{NaOCl})$ como solução de irrigação em endodontia é amplamente difundido e acidentes de extravasamento apical podem ocorrer, sendo na maioria dos casos situações leves a moderadas de manejo simples. No entanto, em pacientes imunossuprimidos, a reação pode ser exacerbada, com implicações sistêmicas significativas e potencialmente fatais. Mesmo assim, há uma falta de informação sobre o manejo desses casos especiais, especialmente em casos oncopediátricos. Portanto, o objetivo é relatar um caso de reação grave pós-acidente com $\mathrm{NaOCl}$ em um adolescente de 13 anos em tratamento quimioterapico, com edema significativo, necrose gengival, erupção cutânea, edema das extremidades, derrame pleural e broncopneumonia, com uma evolução de 30 dias. Entende-se que vários fatores, inclusive anatômicos, podem predispor esta situação, que pode ocorrer mesmo com profissionais experientes e experientes, não necessariamente associados à má prática. Os autores levantam a importância de mais estudos para discutir a real necessidade e indicação do uso do $\mathrm{NaOCl}$ como solução irrigante para estes pacientes e sugerem a adoção de medidas extras de segurança para evitar a ocorrência de situações similares.

Palavras-chave: Hipoclorito de sódio; Neutropenia; Pediatria; Endodontia.

\section{Resumen}

El uso de hipoclorito sódico $(\mathrm{NaOCl})$ como solución de irrigación en endodoncia está muy extendido y pueden producirse accidentes de extravasación apical, siendo en la mayoría de los casos situaciones leves o moderadas de sencillo manejo. Sin embargo, en pacientes inmunodeprimidos, la reacción puede exacerbarse, con cambios sistémicos importantes y potencialmente mortales. Aún así, existe una falta de información sobre el manejo de estos casos especiales, especialmente en los casos oncopediátricos. Por lo tanto, el objetivo es reportar un caso de reacción severa post-accidente con $\mathrm{NaOCl}$ en un adolescente de 13 años en tratamiento de quimioterapia, con edema 
significativo, necrosis gingival, erupción cutánea, edema de las extremidades, derrame pleural y bronconeumonía, con una evolución de 30 días. Se entiende que varios factores, incluso anatómicos, pueden predisponer esta situación, que puede ocurrir incluso con profesionales expertos y experimentados, no necesariamente asociados a una mala práctica. Los autores plantean la importancia de realizar más estudios para discutir la verdadera necesidad e indicación del uso del $\mathrm{NaOCl}$ como solución irrigadora para estos pacientes y sugieren la adopción de medidas de seguridad adicionales para evitar la ocurrencia de situaciones similares.

Palabras clave: Hipoclorito de sodio; Neutropenia; Pediatría; Endodoncia.

\section{Introduction}

Sodium hypochlorite $(\mathrm{NaOCl})$ solutions are widely used as antibacterial agents. However, $\mathrm{NaOCl}$ is cytotoxic and caustic to living tissue when accidental exposure occurs, resulting in an intense inflammatory response (Kashyap et al., 2019; Goswami et al., 2014).

The available guidelines (Farook et al., 2014; Bosch-Aranda et al., 2012; Kanagasingam et al., 2020) do not include cancer patients, especially pediatric ones, who may, due to severe immunosuppression, have disproportionate and unusual reactions. Therefore, our report of a case of life-threatening apical $\mathrm{NaOCl}$ extravasation in a pediatric cancer patient should serve as a warning to our colleagues about potential complications.

Given the extremely high risk of a bad outcome from an accident with $\mathrm{NaOCl}$, especially in this population, our objective is to report a case on the adopted management should promote the discussion on how to care for these patients and perhaps consider the solution as a possible contraindication for pediatric patients with cancer.

\section{Materials and Methods}

The development of this retrospective, descriptive and observational study followed the guidelines for publication, without identifying the patient and with authorization by signing the Informed Consent Form, following the guidelines of the ethics and research committee and the Declaration of Helsinki. The clinical case report study in technical note format, presents a life-threatening case of $\mathrm{NaOCl}$ apical extravasation in a pediatric cancer patient. Epidemiological data, disease history, and photographic records were collected through the patient's physical and electronic medical records. The literary background was performed by searching for keywords (Sodium hypochorite; Neutropenia; Accident; Endodontics), in the databases (Pubmed, Science Direct and Google Scholar).

\section{Results}

A 13-year-old male under antineoplastic treatment for tibial osteosarcoma was referred for external endodontic treatment of superior central incisor due to acute pulpitis six days after receiving Doxorubicin and Cisplatin, with regular laboratory exams. A few hours after the treatment, the mother noticed edema on his upper lip. We considered the day the endodontic treatment took place as D0 to facilitate the understanding of the case; evolution over time is detailed in Table 1. At D4, the patient, under intense oral pain, was hospitalized for febrile neutropenia and presented vestibule ecchymosis, gingival ulceration on the anterior maxilla, and edema on the upper lip. A CT scan showed densification of the soft tissue surrounding the lips, non-specific cervical lymphadenopathy, and edema in the supra-hyoid retropharyngeal space, without collections (Figure 1). The hypothesis of a $\mathrm{NaOCl}$ accident was reinforced after contacting the dentist, who confirmed its use. An x-ray showed cement extravasation, which confirmed apical disruption. The reaction was so severe that on D8, only four days after hospital admission, the patient was placed on the ICU, sedated, put on total parenteral nutrition, with diffuse edema, cutaneous rash on the face, neck, chest, hands and feet, and diagnosed with bronchopneumonia and pleural effusion. At this point, the team felt powerless against the patient's progressively declining health and unresponsiveness to different drugs schemes. After 
the number of neutrophils started improving, a slight recovery began, evolving in the following days until D30, when the patient achieved a full recovery.

Table 1 - Evolution over time in endodontic treatment.

\begin{tabular}{|c|c|c|c|}
\hline DAY & CLINICAL FINDINGS & MANAGEMENT & DRUGS \\
\hline D0 & Upper lip edema. & Observation at home. & Oral analgesia \\
\hline D4 & $\begin{array}{l}\text { Oral pain, fever, ecchymosis in the } \\
\text { anterior superior vestibule, gingival } \\
\text { ulceration from tooth } 21 \text { to } 23 \text { and mild } \\
\text { edema in the upper lip. }\end{array}$ & $\begin{array}{l}\text { Hospitalization for } \\
\text { febrile neutropenia and } \\
\text { oral pain. }\end{array}$ & $\begin{array}{l}\text { Symptomatics } \\
\text { Hydrocortisone } \\
\text { Cefepime } \\
\text { Metronidazol. }\end{array}$ \\
\hline D6 & $\begin{array}{l}\text { Edema spread all over the left side of } \\
\text { the face, with hardened swelling on the } \\
\text { upper lip. }\end{array}$ & $\begin{array}{l}\text { Blood transfusion for } \\
\text { thrombocytopenia. }\end{array}$ & $\begin{array}{l}\text { Symptomatics } \\
\text { Filgrastim } \\
\text { Hydrocortisone } \\
\text { Meropenem }\end{array}$ \\
\hline D7 & $\begin{array}{l}\text { Edema extended to the contralateral } \\
\text { side, and the early ulcerated gingiva } \\
\text { became necrotic. Dyspnea. }\end{array}$ & $\begin{array}{l}\text { Oxygen } 2 \text { liters/minute } \\
\text { in nasal catheter. } \\
\text { Admitted to the ICU. }\end{array}$ & $\begin{array}{l}\text { Symptomatics } \\
\text { Filgrastim } \\
\text { Hydrocortisone } \\
\text { Meropenem } \\
\text { Vancomicyn }\end{array}$ \\
\hline D8 & $\begin{array}{l}\text { Edema and erythema extended to neck } \\
\text { and chest and he was diagnosed with } \\
\text { bronchopneumonia and pleural } \\
\text { effusion } \dagger \\
\text { (Figure 2A) }\end{array}$ & $\begin{array}{l}\text { Started total parenteral } \\
\text { nutrition. }\end{array}$ & $\begin{array}{l}\text { Symptomatics } \\
\text { Filgrastim } \\
\text { Hydrocortisone } \\
\text { Methylprednisolone } \\
\text { Meropenem } \\
\text { Vancomicyn }\end{array}$ \\
\hline D9 & $\begin{array}{l}\text { Reddish spots and edema appeared on } \\
\text { the feet and hands } \dagger \text { (Figure 2B). }\end{array}$ & $\begin{array}{l}\text { Sedation with Ketamine } \\
\text { due to extreme } \\
\text { agitation. }\end{array}$ & $\begin{array}{l}\text { Symptomatics } \\
\text { Filgrastim } \\
\text { Hydrocortisone } \\
\text { Methylprednisolone } \\
\text { Meropenem } \\
\text { Vancomicyn }\end{array}$ \\
\hline D10 & $\begin{array}{l}\text { Slight improvement of edema began } \\
\text { and neutrophils count increased. }\end{array}$ & Observation. & $\begin{array}{l}\text { Symptomatics } \\
\text { Filgrastim } \\
\text { Hydrocortisone } \\
\text { Methylprednisolone } \\
\text { Meropenem } \\
\text { Vancomicyn }\end{array}$ \\
\hline D15 & $\begin{array}{l}\text { Total regression of the facial edema, } \\
\text { with remaining skin desquamation } \\
\text { (Figure } 2 \mathrm{C} \text { ). }\end{array}$ & $\begin{array}{l}\text { Withdraw of sedation. } \\
\text { Transferred from ICU to } \\
\text { infirmary. }\end{array}$ & \\
\hline D30 & $\begin{array}{l}\text { Total resolution of gingival necrosis } \\
\text { and upper lip ulcers. }\end{array}$ & Hospital discharge. & \\
\hline
\end{tabular}

$†$ Clinical features in this case not reported previously.

\$ ICU - Intensive Care Unit.

Source: Authors. 
Figure 1 - A-Clinical aspect at D8, showing diffuse facial edema and erythema extending to neck and upper chest. B -Clinical aspect at D9, showing cutaneous rash and edema on the hand. Similar aspect was observed on the contralateral hand and on the feet. C - Clinical aspect at D15, showing complete regression of the facial edema, but with remaining ulcers on the upper lip and skin desquamation.

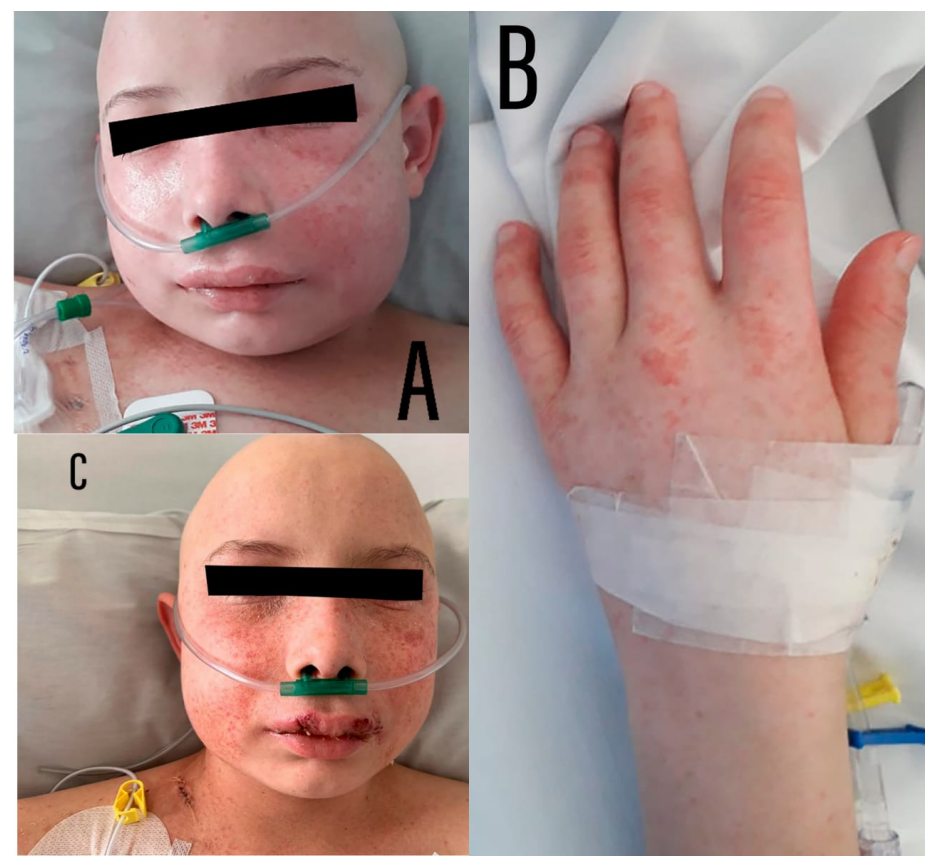

Source: Authors.

Figure 2 - CT scan, sagittal view, showing densification of soft tissues on the upper lip and edema in the retropharyngeal space, without collection.

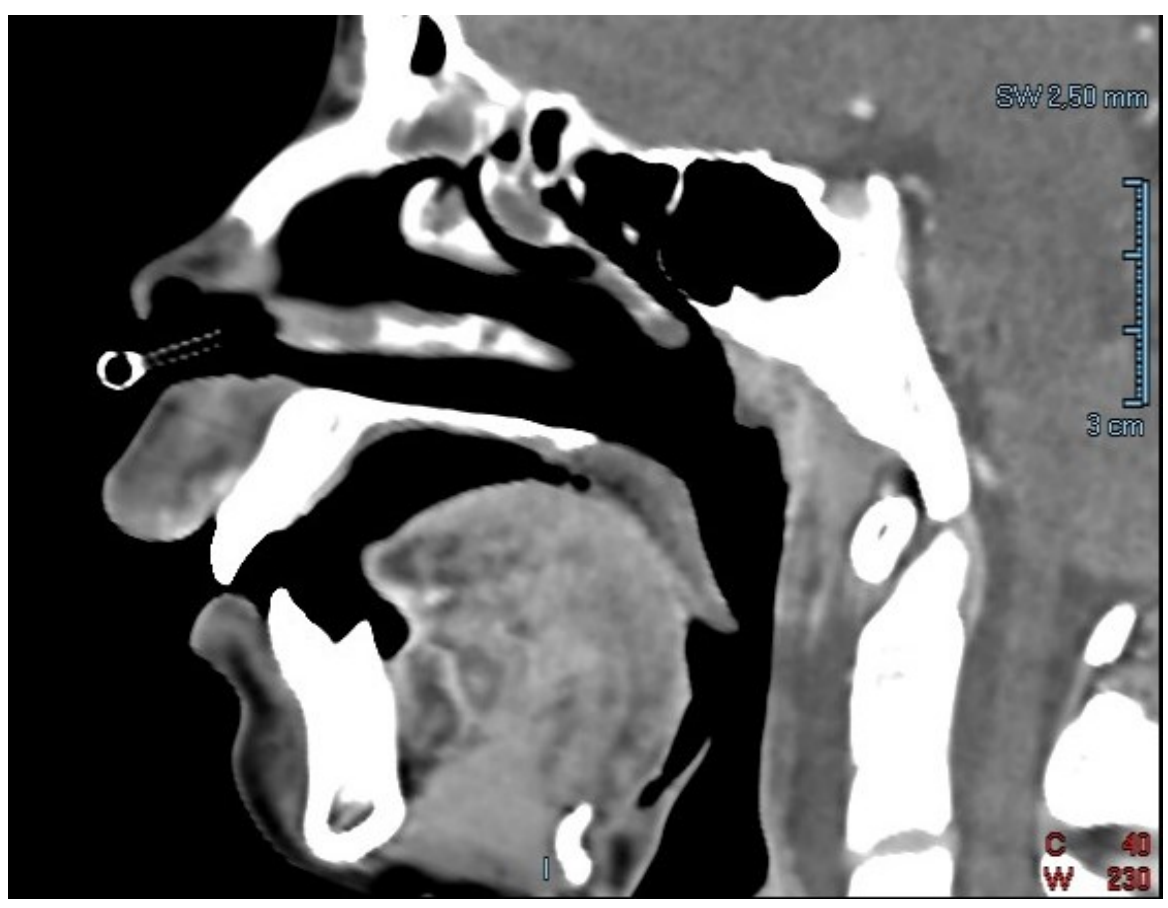

Source: Authors. 


\section{Discussion}

Successful endodontic treatment depends on shaping and cleaning the dental canals, and $\mathrm{NaoCl}$ solution is an important adjuvant (Baumgartner et al., 1992). However, this solution is toxic outside the dental canal (Swanljung et al., 2018), causing inflammatory reactions in the soft tissues, which manifests as pain and localized or diffuse edema (Serpe et al., 2004). Normally, when an accident with $\mathrm{NaOCl}$ occurs, the responsibility lies on the dentist. However, there are other factors that may predispose this situation, such as open apices, periapical lesions, internal and external resorptions, and thinner alveolar bone regions such as the maxilla (Kleier et al, 2008).

In most cases, the edema begins rapidly, on the same day, as does the pain. $\mathrm{NaOCl}$ dissolves organic matter and causes a hemolysis process, which facilitates the absorption of the compound in the superficial facial veins, spreading into the surrounding soft tissues, resulting in ecchymosis and edema (Pashley et al. 1985). Severe cases of $\mathrm{NaOCl}$ accidents report pain, diffuse ecchymosis, edema that may compromise the airway, gingival and mucosal ulcerations (Farook et al., 2014; Guivarc'h et al., 2017; Witton et al., 2005). Severe tissue damage can occur as $\mathrm{NaOCl}$ can cause soft tissue ulceration, rupture red blood cells, inhibit neutrophil migration, injure endothelial and fibroblast cells, cause neurological weakness and necrosis of tissue and cells (Waknis et al., 2011; Hatton et al., 2015; Chaugule et al., 2015; Motta et al., 2009, Ehrich et al., 1993). Some peculiarities of this particular case are the peripheral edema, the disseminated rash on the face, neck, trunk, feet and hands, and pulmonary involvement. When the $\mathrm{NaOCl}$ accident occurred, the child was close to a stage of decline in immunity. The decrease in neutrophil count led to a progressive evolution of symptoms. In four days, this case reached the worst clinical scenario since the patient was unresponsive to medication. Regarding the drug treatment, the main recommendations for severe cases are the opioids for pain control and steroidal anti-inflammatories (Guivarc'h et al., 2017). The use of antimicrobials can reduce the risk of secondary infection, especially in immunocompromised patients. A systematic review on the topic showed that in most cases the antimicrobial of choice was penicillin, sometimes combined with potassium clavulanate or macrolides. Macrolides alone, tetracycline, and cephalosporins were less frequently prescribed. The authors reinforce that the risk of disseminated infection and a weakened immune system should be criteria used when choosing the agent. Antihistamines were used in some cases, seeking to limit the extent of the edema, justified by the release of inflammatory mediators such as histamine in an acute process, which increases vascular permeability (Guivarc'h et al., 2017). In this case, a series of drug regimens were tested, with various associations among broad-spectrum antimicrobials such as cephalosporins, nitroimidazole, carbapenems, and glycopeptides, which were altered with the absence of clinical response and worsening of lung condition. Steroidal anti-inflammatory drugs were used, starting with fast-acting Hydrocortisone and combined Methylprednisolone at the peak of worsening of symptoms. However, in retrospect, the impression is that the patient's condition started improving when the number of neutrophils reached the basal, which was the moment when the organism became able to fight back. We believe that none of the medications was the key to the cure, but that the antimicrobial regimens prevented the development of secondary infection and controlled bronchopneumonia, and that the corticosteroids controlled the expansion of edema avoiding airway obstruction. Finally, it seems that Filgrastim was crucial with stimulation of granulocyte colony formation.

Imaging scans are valuable tools to assist in guiding treatment by identifying collections and showing the extent of tissue damage (Farook et al., 2014). In our case, CT assisted in diagnosis and prognosis, as the retropharyngeal edema indicated a possible respiratory obstruction and alerted the team of the need for mechanical ventilation. It also ruled out the presence of collections, which would complicate the case due to lack of clinical status for surgical drainage. None of the invasive treatments, such as debridement of necrotic areas and tooth extraction, were considered due to severe thrombocytopenia and high anesthetic risk. Local compresses were not applied due to concerns about homeothermia as a result of febrile peaks (Witton et al., 2005; Hulsmann et al., 2000). 


\section{Conclusion}

Sodium hypochlorite accidents are relatively common (Hulsmann et al., 2000; Gatot et al., 1991), although such cases usually recover quickly under more conservative measures. Furthermore, many factors, including anatomical ones, can predispose this situation (Guivarc'h et al., 2017), which may occur even with specialized and experienced professionals, not necessarily associated to bad practice (Guivarc'h et al., 2017). In addition, there are useful guidelines for management in the literature for mild, medium, and severe cases. However, the literature is lacking in guidelines to treat immunosuppressed populations and, to the best of our knowledge, no studies have investigated the treatment of such cases in pediatric cancer populations (Farook et al., 2014). Therefore chlorhexidine gluconate may be recommended as an alternative irrigating solution to $\mathrm{NaOCl}$, especially in cases of open apex, suspected allergies to $\mathrm{NaOCl}$ or in the event of accidental extrusion (Vianna et al., 2004). We stress the importance of new studies to discuss the use of $\mathrm{NaOCl}$ in pediatric cancer patients, in light of the serious and potentially fatal reaction that may occur.

\section{References}

Baumgartner, J. C., \& Cuenin, P. R. (1992). Efficacy of several concentrations of sodium hypochlorite for root canal irrigation. Journal of Endodontics, 18(12).

Bosch-Aranda, M. L., Canalda-Sahli, C., Figueiredo, R., \& Gay-Escoda, C. (2012) Complications following an accidental sodium hypochlorite extrusion: A report of two cases. Journal of Clinical and Experimental Dentistry, 4(3).

Chaugule,V. B., Panse, A. M., \& Gawali, P. N. (2015). International Journal of Clinical Pediatric Dentistry. Int J Clin Pediatr Dent, 8 (2).

Ehrich, D. G., Brian, J. D., \& Walker, W. A. (1993) Sodium hypochlorite accident: Inadvertent injection into the maxillary sinus. Journal of Endodontics, 19(4).

Farook, S.A., Shah, V., Lenouvel, D., Sheikh, O., Sadiq, Z., \& Cascarini, L. (2014.) Guidelines for management of sodium hypochlorite extrusion injuries. British Dental Journal, 217(12)

Gatot, A., Arbelle, J., Leiberman, A., \& Yanai-Inbar, I. (1991). Effects of sodium hypochlorite on soft tissues after its inadvertent injection beyond the root apex. Journal of Endodontics, 17(11)

Guivarc'h, M., Ordioni, U., Ahmed, H. M. A., Cohen, S., Catherine, J. H. \& Bukiet F. (2017). Sodium Hypochlorite Accident: A Systematic Review. Journal of Endodontics, 43(1).

Goswami, M., Chhabra, N., Kumar, G., Verma, M., \& Chhabra, A. (2014). Sodium hypochlorite dental acidentes. Paediatrics and International Child Health, 34 (1), DOI 10.1179/2046905512Y.0000000042

Hatton, J., Walsh, S., \& Wilson, A. (2015) Management of the sodium hypochlorite accident: A rare but significant complication of root canal treatment. BMJ Case Reports.

Hulsmann, M., \& Hahn, W. (2000) Complications during root canal irrigation - literature review and case reports. International Endodontic Journal [Internet],33(3). doi.wiley.com/10.1046/j.1365-2591.2000.00303.x

Kanagasingam, S., \& Blum, I. R. (2020) Sodium Hypochlorite Extrusion Accidents: Management and Medico-Legal Considerations. Primary dental jornal, 9(4). Dental Science, 18.

Kashyap, N., Upadhyay, M., Sharma, J., Das, S. J., \& Katlam, T. (2019). Irrigating Solutions in Pediatric Dentistry: A Big Deal in Little Teeth. EC.

Kleier, D. J., Averbach, R. E. \& Mehdipour O. (2008). The Sodium Hypochlorite Accident: Experience of Diplomates of the American Board of Endodontics. Journal of Endodontics, 34(11).

Motta, M. V., Chaves-Mendonca, M. A. L., Stirton, C. G., \& Cardozo, H. F. (2009). Accidental injection with sodium hypochlorite: Report of a case. International Endodontic Journal, 42(2).

Pashley, E. L., Birdsong, N. L., Bowman, K., \& Pashley, D. H. (1985) Cytotoxic effects of NaOCl on vital tissue. Journal of Endodontics, 11(12).

Serper, A., Ozbek, M., \& Çalt, S. (2004). Accidental Sodium Hypochlorite-Induced Skin InjuryDuring Endodontic Treatment. Journal ofendodontics, 30 (3).

Swanljung, O., \& Vehkalahti, M. M. (2018). Root Canal Irrigants and Medicaments inEndodontic Malpractice Cases: A NationwideLongitudinal Observation. American Association of Endodontists. 44(4), doi.org/10.1016/j.joen.2018.01.003

Vianna, M. E., Gomes, B. P. F. A., Berber, V. B., Zaia, A. A., Ferraz, C. C. R., \& Souza-Filho, F. J. (2004) In vitro evaluation of the antimicrobial activity of chlorhexidine and sodium hypochlorite. Oral Surgery, Oral Medicine, Oral Pathology, Oral Radiology, and Endodontics, 97(1).

Witton, R., Henthorn, K., Ethunandan, M., Harmer, S., \& Brennan, P. A. (2005). Neurological complications following extrusion of sodium hypochlorite solution during root canal treatment. International Endodontic Journal, 38(11).

Waknis, P. P., Deshpande, A. S., \& Sabhlok, S. (2011). Accidental injection of sodium hypochlorite instead of local anesthetic in a patient scheduled for endodontic procedure. Journal of Oral Biology and Craniofacial Research, 1 (1). 